\title{
Expansion of T regulatory lymphocytes by murine bone marrow dendritic cells previously stimulated with Anisakis simplex larval antigens
}

\author{
Vega Zamora', Marta Rodero', Alexandra Ibáñez-Escribano', \\ Juan C Andreu-Ballester², Susana Mendez ${ }^{3}$, Carmen Cuéllar ${ }^{1 /+}$ \\ ${ }^{1}$ Universidad Complutense, Facultad de Farmacia, Departamento de Microbiología y Parasitología, Madrid, Spain \\ ${ }^{2}$ Hospital Arnau de Vilanova, Departamento de Investigación, Valencia, Spain \\ ${ }^{3}$ National Institutes of Health, National Institute of Allergy and Infectious Diseases, Division of Microbiology and Infectious Diseases, \\ Respiratory Disease Branch, Rockville, MD, EUA
}

BACKGROUND Anisakis simplex antigens present immunomodulatory properties by the induction of tolerogenic dendritic cells (DCs) in mice.

OBJECTIVES To study the capacity of DCs stimulated with A. simplex excretory-secretory (ES) or crude extract (CE) to generate $\mathrm{T}_{\text {regs }}$. To investigate in vitro effects of antigens on the metabolic activity of splenocytes induced by LPS or CpG.

METHODS Phenotypic and functional characterization of T cells co-cultured with $A$. simplex-pulsed DCs was performed by flow cytometry. Lymphocyte mitochondrial respiratory activity was estimated by the Alamar Blue ${ }^{\circledR}$ Assay.

FINDINGS In C57BL/6J, CD $4^{+} \mathrm{CD} 25^{-}$Foxp $^{+}$and $\mathrm{CD}^{+}{ }^{+} \mathrm{CD} 25^{-} \mathrm{Foxp}^{+}{ }^{+}$populations increased by CE-stimulated-DCs. In BALB/c, CE-stimulated-DCs caused the expansion of $\mathrm{CD} 4^{+} \mathrm{CD} 25^{+} \mathrm{Foxp} 3^{+} \mathrm{IL}-10+$ and $\mathrm{CD} 8^{+} \mathrm{CD} 25^{+} \mathrm{Foxp} 3^{+} \mathrm{IL}-10+$. IFN- $\gamma$ expression raised in $\mathrm{BALB} / \mathrm{c} \mathrm{CD} 4^{+} \mathrm{CD} 25^{+}$and $\mathrm{CD} 4^{+} \mathrm{CD} 25^{-}$for $\mathrm{CE}$ and $\mathrm{ES}$, respectively. ES-stimulated-DCs increased $\mathrm{CD} 4^{+} \mathrm{CD} 25^{+} \mathrm{Foxp}^{+}$and $\mathrm{CD} 8^{+} \mathrm{CD} 25^{-}$Foxp $^{+}$expression in T cells. The association of ES or CE with LPS produced the increase in splenocyte activity in C57BL/6J. The association of $\mathrm{CE}$ with $\mathrm{CpG}$ decreased the proliferation caused by CpG in C57BL/6J.

MAIN CONCLUSIONS A. simplex increase the frequency of $\mathrm{T}_{\text {regs }}$, which in turn produce IL-10 and IFN- $\gamma$. The host genetic base is essential in the development of anti-Anisakis immune responses (Th2, Th1, $\mathrm{T}_{\mathrm{reg}}$ ).

Key words: Anisakis simplex - mice - tolerogenic dendritic cells - T regulatory cells - IL-10 - mitochondrial activity

In a previous work, immunomodulatory properties of Anisakis simplex larval antigens were demonstrated by the induction of tolerogenic dendritic cells (DCs) in two strains of mice (C57BL/6J and BALB/c). ${ }^{(1)}$ DC's antigen-presenting ability was determined by measuring the expression of membrane markers (MHC I and MHC II, CD80, CD86) and intracellular expression levels of IL-10 and IL-12 cytokines. It was also analyzed whether stimulation with $A$. simplex larval antigens was enhanced by the co-administration of TLR4 and TLR9 agonists [LPS Escherichia coli 026B6 and CpG (ODN1826), respectively]. Two differential types of responses were found in the mouse strains studied: C57BL/6J mice developed a more discrete and resistant response, whereas the BALB/c strain showed an acute inflammatory response. These results demonstrate the

doi: 10.1590/0074-02760200560

Financial support: Fundación Ramón Areces (XV Concurso Nacional para

la Adjudicación de Ayudas a la Investigación en Ciencias de la Vida y de

la Materia - project "Study of the immunomodulatory effects of Anisakis

simplex larval antigens").

+ Corresponding author: cuellarh@ucm.es

(1) https://orcid.org/0000-0001-7948-9889

Received 29 October 2020

Accepted 08 January 2021 coexistence of two opposing responses generated by $A$. simplex larval antigens (Th1 versus $\mathrm{Th} 2$ ), and confirmed that the host genetic basis plays a role in the development of a Th2 or a T regulatory $\left(\mathrm{T}_{\text {reg }}\right)$ response.

Larval products of $A$. simplex slightly increased the proinflammatory cytokine IL-12 characteristic of the Th1 effector response and the suppressive cytokine IL10 characteristic of the Th2 effector response in vitro. Several studies have shown that the expression of IL10 and IL-12 are closely related in such a way that the production of IL-10 and IL-12 by DCs presents a close reciprocal regulation. ${ }^{(2)}$ This indicates a possible immunomodulatory mechanism by $A$. simplex larval antigens through these two cytokines, establishing a balance between a Th1 and the Th2 response. Infections with other parasites, like Schistosoma spp. or Trichinella spiralis, have shown the same balance. ${ }^{(3,4)}$ Several studies have demonstrated that the simultaneous development of Th1 and Th2 anthelminthic immune responses not only limits microbial invasion during the barrier breach, but also promotes tissue repair/regeneration. ${ }^{(5)}$ In addition, Allen and $\mathrm{Wynn}^{(6)}$ proposed that Th2 immunity evolved to rapidly repair tissue damage caused by helminth parasites instead of controlling them.

Definitely, there are many potential mechanisms of helminth-induced modulation. They include helminthderived products that act on DCs and Treg cell-inducing helminth-derived molecules have been described. ${ }^{(7)}$ 
In light of these findings, we evaluated the capacity of DCs stimulated with A. simplex larval products to generate $\mathrm{T}_{\text {regs }}$. In addition, we investigated the in vitro effect of larval antigens of $A$. simplex on the metabolic activity of mouse splenocytes induced by LPS or $\mathrm{CpG}$ (ODN1826).

\section{MATERIALS AND METHODS}

Animals - Female C57BL/6J and BALB/c mice were purchased from Charles River Laboratories (L'Arbresle, France). The authors have involved the minimum number of animals to produce statistically reproducible results. All procedures were carried out in accordance with Royal Decree 53/2013, of 1 February, which establishes the basic rules applicable for the protection of animals used in experimentation and other scientific purposes. The project was approved by the Ethics Committee of the Complutense University of Madrid and evaluated and approved by an authorized body authorized by the Community of Madrid for the evaluation of Projects.

In vitro bone marrow-derived dendritic cells stimulation assays - Bone marrow-derived DCs (BMDDCs) were cultured in the presence of $20 \mathrm{ng} / \mathrm{mL}$ GM-CSF (PeproTech, Rocky Hill, NJ) and collected six days after culture. DCs were then plated in 6-well plates $\left(10^{6} /\right.$ well) before $A$. simplex antigens (excretory-secretory/ES or crude extract/CE) were added to the wells. Antigens were prepared as previously described. ${ }^{(8)}$ Different stimuli were employed: ES $(0.012 \mu \mathrm{g} / \mathrm{mL})$ or CE $(50 \mu \mathrm{g} / \mathrm{mL})$ for 24 hours $\left(\mathrm{CO}_{2} 5 \%, 37^{\circ} \mathrm{C}\right) .{ }^{(1)} \mathrm{A}$ control of DCs cultured in medium without antigens was included in all the experiments. All experiments were performed in triplicate wells for each condition and repeated at least three times. We used the Pierce LAL Chromogenic Endotoxin Quantitation Kit (Thermo Fisher Scientific, Rockford, IL) for the detection of gram-negative bacterial endotoxins. The amounts of endotoxin present in our antigenic samples were negligible compared to the doses of $1 \mu \mathrm{g} /$ $\mathrm{mL}$ of LPS used as positive control.

Phenotypic and functional characterization of T cells co-cultured with Anisakis simplex antigens-pulsed bone marrow-derived dendritic cells - Splenocytes were puri- fied from spleens of naïve $\mathrm{C} 57 \mathrm{BL} / 6 \mathrm{~J}$ or $\mathrm{BALB} / \mathrm{c}$ mice by mechanical disruption. Prior to co-culture, red blood cells were lysed for 10 minutes with cold Red Blood Cell Lysing Buffer (SIGMA-ALDRICH). Purified cells were added to cultures containing BMDDCs (five splenocytes: one DC ratio) that have been left unstimulated or had been treated with $A$. simplex antigens. Thirty-six hours after initiation of the co-culture, brefeldin A (Penicilium brefeldianum, Life Technologies) $(10 \mu \mathrm{g} / \mathrm{mL})$ was added for $6 \mathrm{~h}$; cells were then collected and fixed in $4 \%$ paraformaldehyde. Prior to staining, cells were incubated with an anti-Fc $\gamma$ III/II receptor and 10\% normal mouse serum in phosphate buffered saline (PBS) containing $0.1 \%$ bovine serum albumin (BSA), $0.01 \% \mathrm{NaN}_{3}$. Cells were permeabilized with saponin and stained for the surface markers CD4 [PerCP Rat Anti-Mouse CD4 (BD-Pharmingen)], CD8 [PerCP Rat Anti-Mouse CD8a (BD-Pharmingen)], CD25 [Anti-Mouse CD25 APC (eBioscience)]; for the cytokines IL-12 [Anti-Mouse IL-12/IL-23p40 PE (eBioscience)], IL-10 [PE Rat AntiMouse IL-10 (BD Biosciences)], IFN- $\gamma$ [Anti-Mouse IFN gamma PE (eBioscience)], and the transcription factor Foxp3 [Anti-Mouse/Rat Foxp3 Staining Set PE (eBioscience)]. We carried out incubations of antibodies against surface molecules and intracellular cytokines on ice, for $30 \mathrm{~min}$ and $40 \mathrm{~min}$, respectively. Staining of Foxp3 was made following the specific protocol of the manufacturer of the kit. For each sample, at least 20,000 cells were collected using FACSCan/FACSCalibur flow cytometer and CELLQuest software (Becton Dickinson, San Jose, CA) in the Cytometry and Microscopy Center of the Complutense University of Madrid. The data were analysed by Flowing software.

Splenocyte proliferation assay - Purified splenocytes from BALB/c and C57BL/6J mice were stimulated with the $A$. simplex antigens as above and/or with the positive controls: LPS ${ }_{\text {E.coli } 026 \mathrm{BB} 6}(1 \mu \mathrm{g} / \mathrm{mL})$ and $\mathrm{CpG}(\mathrm{ODN} 1826)(50$ $\mu \mathrm{g} / \mathrm{mL}$ ). All the conditions for the in vitro assay were previously standardized. As negative controls splenocytes incubated in RPMI were used. Lymphocyte mitochondrial respiratory activity was estimated by a fluorometric method using the redox dye resazurin. A stock solution
A

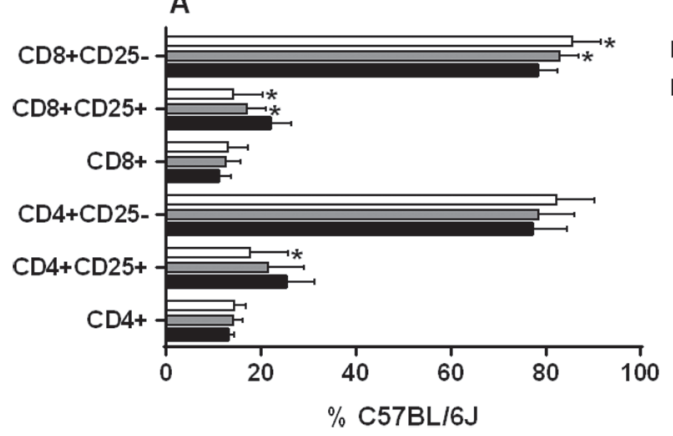

B

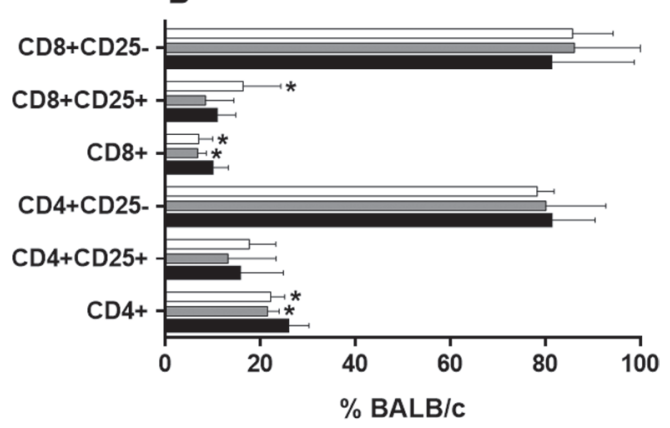

Fig. 1: percentages of $\mathrm{T}$ cell subsets after $48 \mathrm{~h}$ of co-culture of mice splenocytes and bone marrow-derived dendritic cells (BMDDCs) previously stimulated with Anisakis simplex larval antigens [excretory-secretory (ES) or crude extract (CE)]. Panel A. C57BL/6J. Panel B. BALB/c. Percentages of total $\mathrm{CD} 4^{+}$or $\mathrm{CD} 8^{+}, \mathrm{CD} 4^{+} \mathrm{CD} 25^{+}$or $\mathrm{CD} 4^{+} \mathrm{CD} 25^{-}$and $\mathrm{CD} 8^{+} \mathrm{CD} 25^{+}$or $\mathrm{CD} 8^{+} \mathrm{CD} 25^{-}$cells. Data are expressed as mean \pm standard deviation (SD) of data from three independent experiments. Asterisk indicates statistically significant differences respect to the control, ${ }^{*} \mathrm{p}<0.05$. 

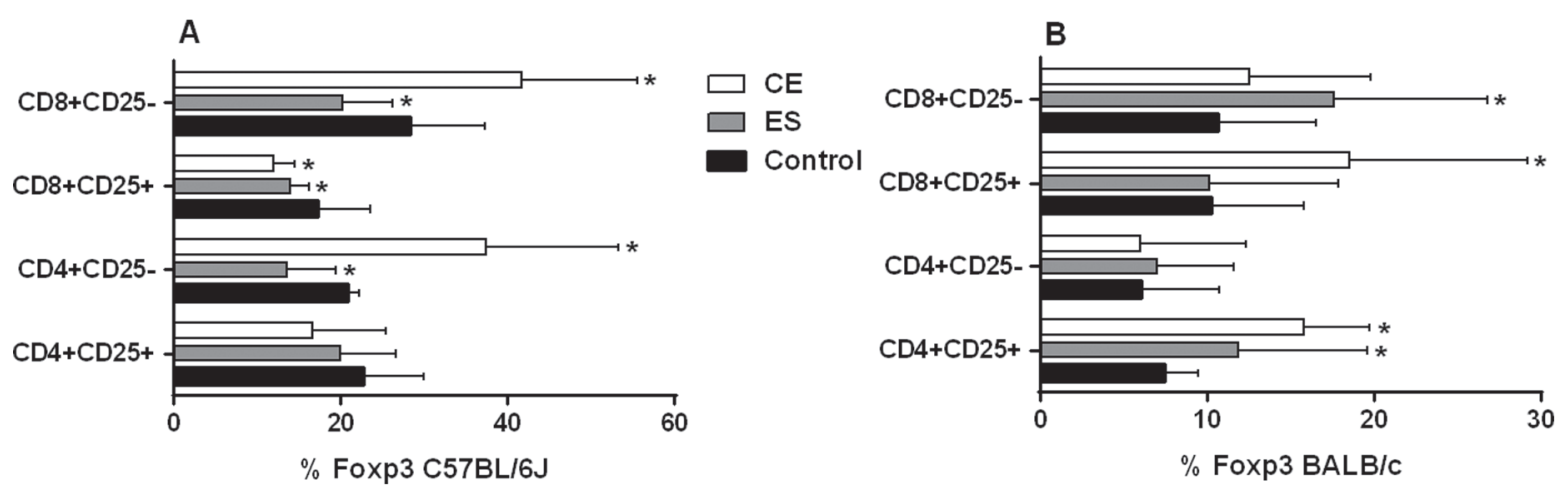

Fig. 2: percentages of $\mathrm{T}$ cell subsets after $48 \mathrm{~h}$ of co-culture of mice splenocytes and bone marrow-derived dendritic cells (BMDDCs) previously stimulated with Anisakis simplex larval antigens [excretory-secretory (ES) or crude extract (CE)]. Panel A C57BL/6J. Panel B: BALB/c. Percentages of $\mathrm{CD} 4^{+} \mathrm{CD} 25^{+}$or $\mathrm{CD} 4^{+} \mathrm{CD} 25^{-}$and $\mathrm{CD} 8^{+} \mathrm{CD} 25^{+}$or $\mathrm{CD} 8^{+} \mathrm{CD} 25^{-}$that express Foxp3. Data are expressed as mean \pm standard deviation (SD) of data from three independent experiments. Asterisk indicates statistically significant differences respect to the control, ${ }^{*} \mathrm{p}<0.05$.

(10 $\mathrm{mM})$ of resazurin sodium salt (Sigma-Aldrich) was prepared in PBS and stored at $4^{\circ} \mathrm{C}$ protected from light. This assay was carried out using a suspension of splenocytes $\left(7.5 \times 10^{5}\right.$ cells $\left./ \mathrm{mL}\right)$ in RPMI supplemented with $10 \%(\mathrm{v} / \mathrm{v})$ heat-inactivated serum. Cells were seeded in sterile 96 well microtiter plate $(200 \mu \mathrm{L} /$ well; 150,000 lymphocytes/well) with the different stimuli. After 1, 24 and $48 \mathrm{~h}$ of incubation at $37^{\circ} \mathrm{C}$ and $5 \% \mathrm{CO}_{2}, 20 \mu \mathrm{L} /$ well of resazurin were added $(1 \mathrm{mM})$. The reduction of resazurin into the fluorescent dye resorufin by the reductase activity of splenocytes was sequentially measured during the culture period in a plate fluorimeter (Infinite 200, TECAN) at $\lambda_{\text {excitation }}: 535 \mathrm{~nm}$ and $\lambda_{\text {emission }}: 590 \mathrm{~nm}$ following the Alamar Blue ${ }^{\circledR}$ Assay (US Patent 5,501,959) recommendations. Experiments were carried out for both mouse strains (BALB/c and C57BL/6J) at least four times. A resazurin control in PBS without cells was included in all the plates. The fluorescence derived from the spontaneous oxidation of the probe was subtracted from the fluorometric results of the test samples. In order to estimate the mitochondrial respiratory activity of each sample stimulation indexes (SI) were calculated for each resazurin incubation interval.

Statistics - Data are presented as mean \pm standard deviation (SD). Differences were analyzed for significance. Non-parametric tests were performed (Wilcoxon and Monte Carlo Tests) to compare the means. To compare groups of stimuli, Mann-Whitney U Test was used. One-way analysis of variance (ANOVA) followed by the Tukey's honest significant difference post-hoc test was applied to evaluate differences in SI for the resazurin assay (SPSS 19, Inc., Chicago, IL, USA). A p value less than 0.05 was used as the threshold for significance.

\section{RESULTS}

Co-incubation of splenic cells with bone marrowderived dendritic cells pulsed with Anisakis simplex antigens - The following populations were analyzed: $\mathrm{CD}^{+}$ and $\mathrm{CD}^{+} \mathrm{T}$ cells; and the subpopulations $\mathrm{CD} 4^{+} \mathrm{CD} 25^{+}$, $\mathrm{CD} 8^{+} \mathrm{CD} 25^{+}, \mathrm{CD} 4^{+} \mathrm{CD} 25^{-}$and $\mathrm{CD} 8^{+} \mathrm{CD} 25^{-} \mathrm{T}$ cells. In addition, we measured the cell percentages that express IL10 and IFN- $\gamma$. We also determined the expression of the transcription factor Foxp3.
C57BL/6J BMDDCs previously stimulated with $\mathrm{CE}$ caused a significant increase in the frequency of $\mathrm{CD}^{+} \mathrm{CD} 25^{-} \mathrm{T}$ cells $(\mathrm{p}<0.05)$ (Fig. 1A). Likewise, the number of $\mathrm{CD}_{2} 5^{+}$total cells was decreased compared to the negative control $\left(\mathrm{p}<0.05\right.$ for $\mathrm{CD}^{+} \mathrm{CD} 25^{+}$and $\mathrm{CD}^{+} \mathrm{CD} 25^{+} \mathrm{T}$ cells) (Fig. 1A). When cells were stimulated with ES products, the percentage of $\mathrm{CD} 8^{+} \mathrm{CD} 25^{-} \mathrm{T}$ cells was increased, while the $\mathrm{CD} 8^{+} \mathrm{CD} 25^{+} \mathrm{T}$ cell subset was diminished (both $\mathrm{p}<0.05$ ) (Fig. 1A). Interestingly, C57BL/6J BMDDCs previously stimulated with $\mathrm{CE}$ achieved higher rates of $\mathrm{CD} 4^{+} \mathrm{CD} 25^{-}{ }^{-}$oxp $3^{+}$cells and $\mathrm{CD}^{+} \mathrm{CD} 25^{-} \mathrm{Foxp}^{+}$cells compared to the negative control, although ES exhibited the opposite response $(p<0.05)$ (Fig. 2A). Significant differences were found between $\mathrm{CE}$ and ES for Foxp3 expression in both $\mathrm{CD}^{+} \mathrm{CD} 25^{-}(\mathrm{p}<$ $0.05)$ and $\mathrm{CD}^{+} \mathrm{CD} 25^{-} \mathrm{T}$ cells $(\mathrm{p}<0.01)$ (Fig. $\left.2 \mathrm{~A}\right)$.

Concerning cytokine expression, an inhibitory response was observed in $\mathrm{C} 57 \mathrm{BL} / 6 \mathrm{~J} \mathrm{CD} 4^{+} \mathrm{CD} 25^{+}$and $\mathrm{CD} 8^{+} \mathrm{CD} 25^{+}$activated $\mathrm{T}$ cells in almost all conditions analyzed when compared to the negative control. This difference was significant in ES-treated $\mathrm{CD} 8^{+} \mathrm{CD} 25^{+} \mathrm{IL}-10^{+}$ $\mathrm{T}$ cells and in $\mathrm{CE}$ and ES-treated $\mathrm{CD} 8^{+} \mathrm{CD} 25^{+} \mathrm{IFN}-\gamma^{+}$ $\mathrm{T}$ cells $(\mathrm{p}<0.05)$ (Fig. 3A-B). Finally, BMDDCs previously stimulated with $\mathrm{CE}$ promoted the expansion of $\mathrm{CD}^{+} \mathrm{CD} 25^{-} \mathrm{IL}-10^{+}$(Fig. 3A), CD4 ${ }^{+} \mathrm{CD} 25-\mathrm{IFN}_{-} \gamma^{+}$and $\mathrm{CD} 8^{+} \mathrm{CD} 25-\mathrm{IFN}-\gamma^{+} \mathrm{T}$ cells with a trend towards significance (Fig. 3B). This trend was confirmed in the case of CD $4^{+} \mathrm{CD} 25^{-} \mathrm{T}$ cells, which showed a significant increase of the ratio $\mathrm{IFN}-\gamma^{+} / \mathrm{IL}-10^{+}$expression after $\mathrm{CE}$ and $\mathrm{ES} /$ BMDDC stimulation ( $\mathrm{p}<0.05)$ (Fig. 4A).

When experiments were carried out using BALB/c cells, stimulation of BMDDCs with ES or CE caused a significant decreased of percentages of total $\mathrm{CD}^{+}$and $\mathrm{CD}^{+} \mathrm{T}$ cells compared to the negative control $(\mathrm{p}<0.05)$ (Fig. 1B). Also, the percentages of $\mathrm{CD}^{+} \mathrm{CD} 25^{+} \mathrm{Foxp}^{+}$ and $\mathrm{CD} 8^{+} \mathrm{CD} 25^{+} \mathrm{Foxp}^{+} \mathrm{T}_{\text {regs }}$ were significantly increased by BALB/c BMDDCs stimulated with $\mathrm{CE}$; ES, however, promoted Foxp3 expression by both $\mathrm{CD} 4^{+} \mathrm{CD} 25^{+}$and $\mathrm{CD}^{+} \mathrm{CD} 25^{-} \mathrm{T}$ cell subsets $(\mathrm{p}<0.05)$ (Fig. 2B). Moreover, $\mathrm{CE}$ and ES significantly increased $\mathrm{CD} 4^{+} \mathrm{CD} 25^{+} \mathrm{IFN}-\gamma^{+}$ and $\mathrm{CD} 4^{+} \mathrm{CD} 25^{-} \mathrm{IFN}-\gamma^{+} \mathrm{T}$ cells, respectively $(\mathrm{p}<0.05)$ (Fig. 3D). However, the expression of $\mathrm{CD}^{+} \mathrm{CD} 25^{+} \mathrm{IFN}-\gamma^{+}$ $\mathrm{T}$ cells was inhibited by $\mathrm{CE}$ antigens with a trend towards 

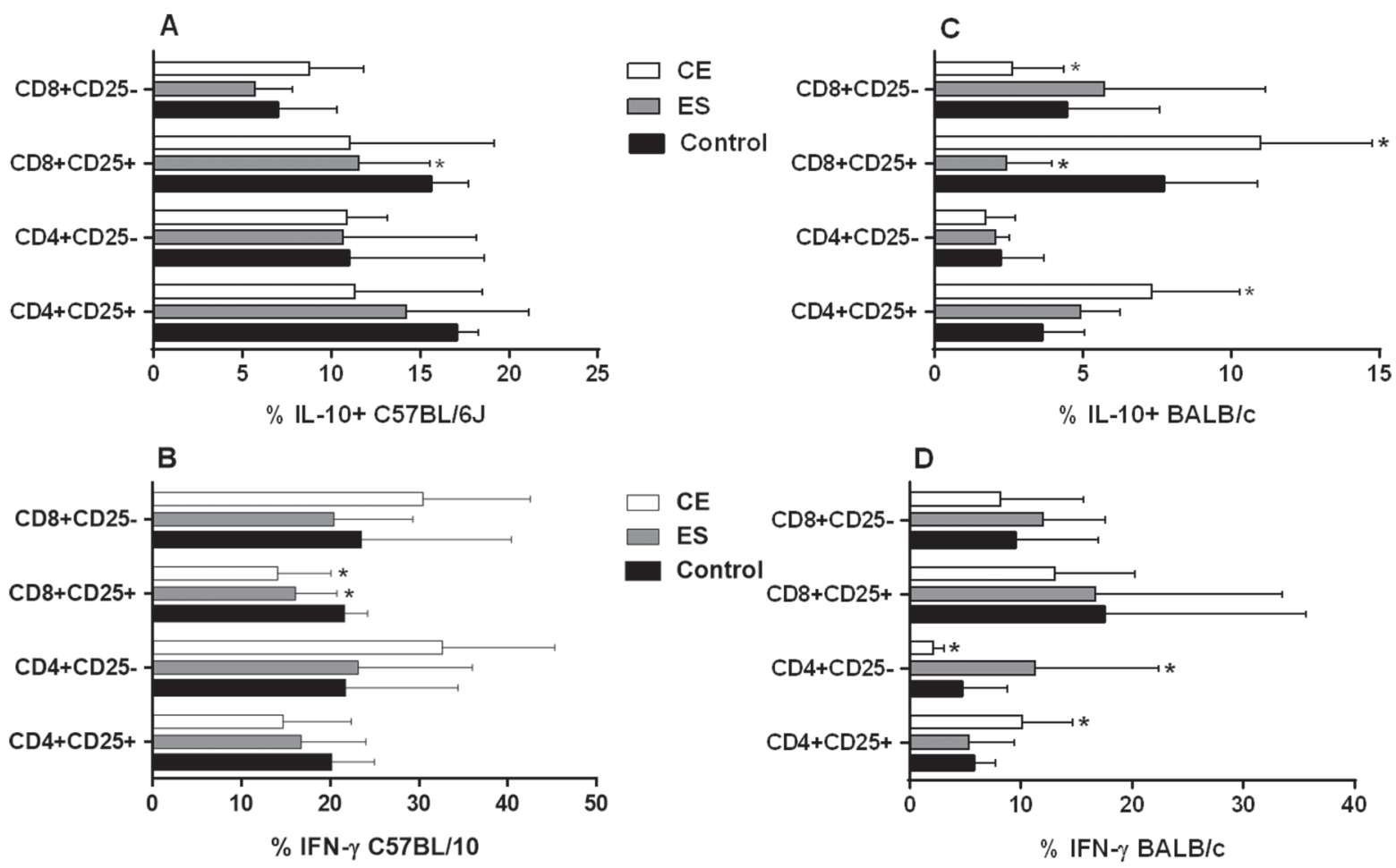

Fig. 3: percentages of $\mathrm{T}$ cell subsets after $48 \mathrm{~h}$ of co-culture of mice splenocytes and bone marrow-derived dendritic cells (BMDDCs) previously stimulated with Anisakis simplex larval antigens [excretory-secretory (ES) or crude extract (CE)]. Panels A and B: C57BL/6J. Panels C and D: BALB/c. Percentages of $\mathrm{CD} 4^{+} \mathrm{CD} 25^{+}$or $\mathrm{CD} 4^{+} \mathrm{CD} 25^{-}$and $\mathrm{CD} 8^{+} \mathrm{CD} 25^{+}$or $\mathrm{CD} 8^{+} \mathrm{CD} 25^{-}$that express IL-10 or IFN- $\gamma$. Data are expressed as mean \pm standard deviation (SD) of data from three independent experiments. Asterisk indicates statistically significant differences respect to the control, ${ }^{*} \mathrm{p}<0.05$.
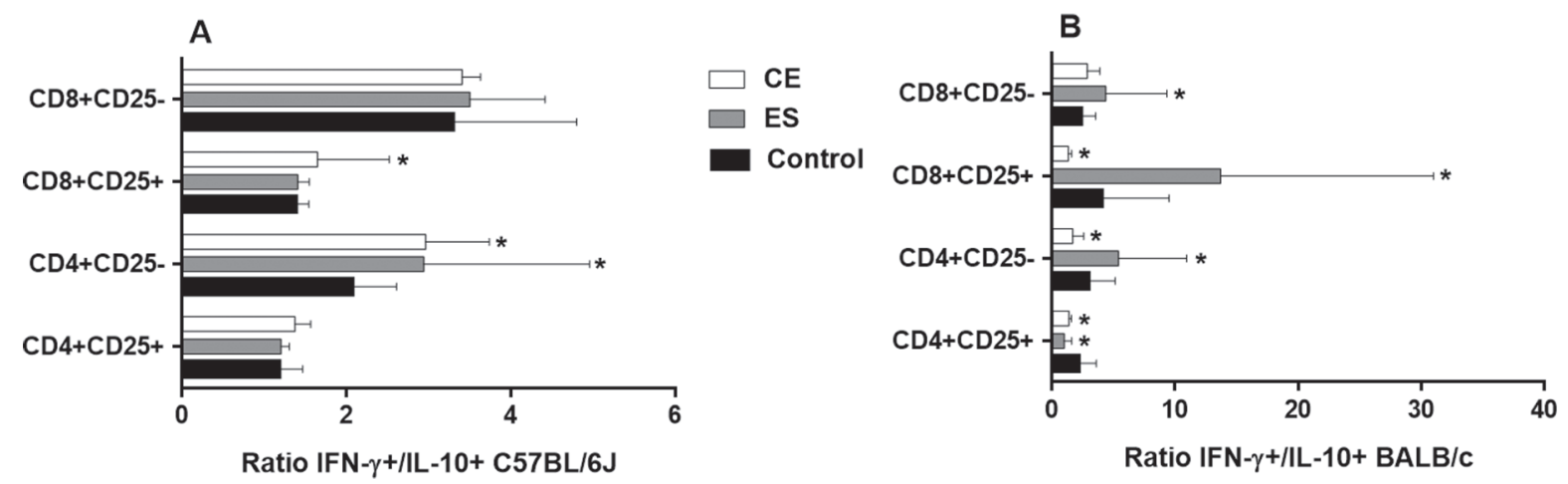

Fig. 4: ratio of IFN- $\gamma / \mathrm{IL}-10$ expression in $\mathrm{CD}^{+} \mathrm{CD} 25^{+}, \mathrm{CD} 4^{+} \mathrm{CD} 25^{-}, \mathrm{CD} 8^{+} \mathrm{CD} 25^{+}$and $\mathrm{CD} 8^{+} \mathrm{CD} 25^{-} \mathrm{T}$ cell subsets after $48 \mathrm{~h}$ of co-culture of mice splenocytes and bone marrow-derived dendritic cells (BMDDCs) previously stimulated with Anisakis simplex larval antigens [excretorysecretory (ES) or crude extract (CE)]. Panel A: C57BL/6J. Panel B: BALB/c. Data are expressed as mean \pm standard deviation (SD) of data from three independent experiments. Asterisk indicates statistically significant differences respect to the control, ${ }^{*} \mathrm{p}<0.05$.

significance compared to the negative control (Fig. 3D), as demonstrated by the significant decrease of the ratio IFN- $\gamma^{+} / \mathrm{IL}-10^{+}$presented in the Fig. 4B $(\mathrm{p}<0.05)$. The same trend was observed in the $\mathrm{CD} 4^{+} \mathrm{CD} 25^{+} \mathrm{T}$ cell subset, where stimulation of BMDDCs with CE and ES induced a significantly reduction of the ratio of $\mathrm{IFN}-\gamma^{+} /$ IL-10+ $\mathrm{T}$ cells $(\mathrm{p}<0.05)$ (Fig. 4B). Moreover, CE exposure of BALB/c BMDDCs boosted the proliferation of $\mathrm{CD}^{+} \mathrm{CD} 25^{+} \mathrm{IL}-10^{+}$as well as of $\mathrm{CD} 8^{+} \mathrm{CD} 25^{+} \mathrm{IL}-10^{+} \mathrm{T}$ cell subsets $(\mathrm{p}<0.05)$ (Fig. 3C). Subsequently, the ratio of IFN $-\gamma^{+} / \mathrm{IL}-10^{+} \mathrm{T}$ cells was significantly reduced in both
$\mathrm{T}_{\text {reg }}$ populations $(\mathrm{p}<0.05)$ (Fig. 4B). On the other hand, ES stimulation of BALB/c BMDDCs not only lead to a significant decrease of $\mathrm{CD} 8^{+} \mathrm{CD} 25^{+} \mathrm{IL}-10^{+} \mathrm{T}$ cells compared with $C E(p<0.01)$ (Fig. $3 C)$, but also amplified the ratio of IFN- $\gamma^{+} / \mathrm{IL}-10^{+} \mathrm{T}$ cells in this cell subset as well as in the $\mathrm{CD} 8^{+} \mathrm{CD} 25^{-} \mathrm{T}$ cell population $(\mathrm{p}<0.05)$ (Fig. 4B).

Splenocyte proliferation assay - SI of C57BL/6J or BALB/c mouse splenocytes were calculated following $1 \mathrm{~h}$ incubation with ES or CE or medium alone and in combination with LPS and CpG. Resazurin was then 
A

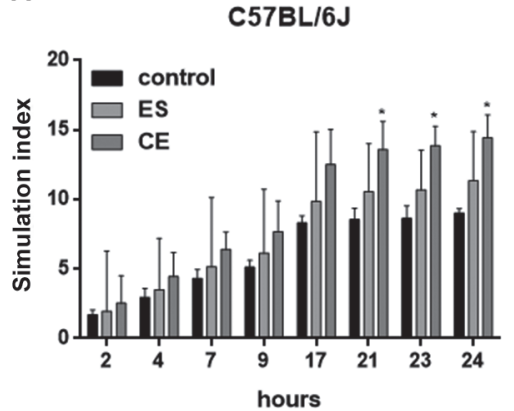

D

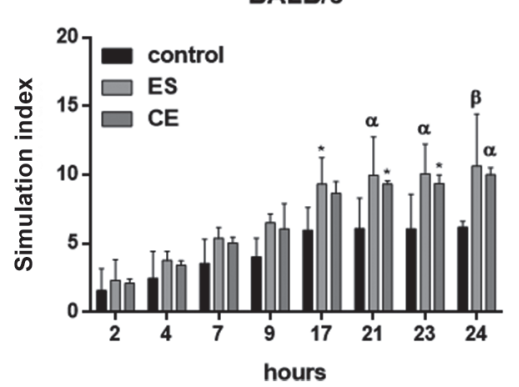

B

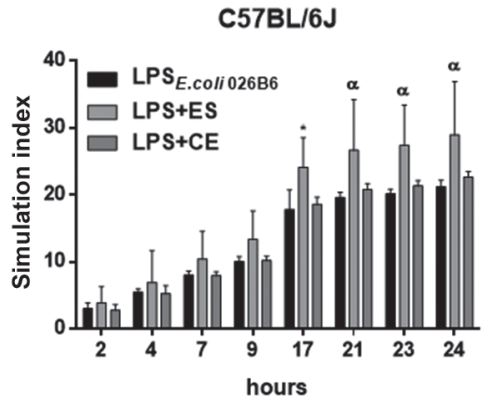

E

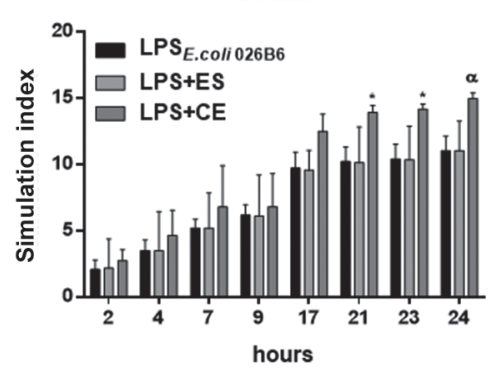

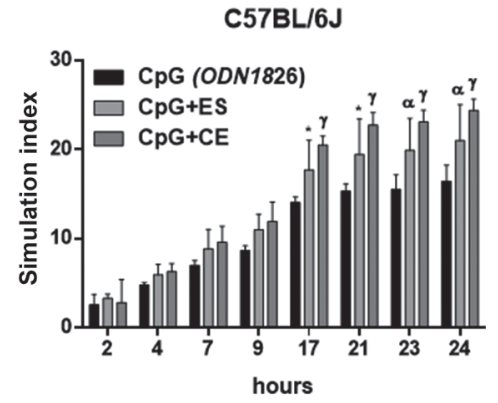

$\mathbf{F}$

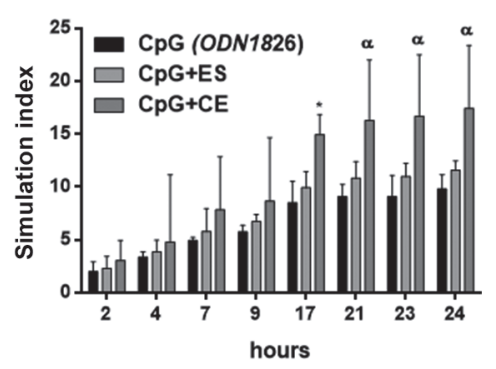

Fig. 5: stimulation index (SI) of C57BL/6J or BALB/c mouse splenocytes after $1 \mathrm{~h}$ of stimulation with Anisakis simplex ES or CE or medium alone (Panels A and D), with LPS E. coli $026 \mathrm{~B} 6_{6}$ alone or associated with A. simplex excretory-secretory (ES) or crude extract (CE) (Panels B and E) or with CpG (ODN1826) alone or associated with A. simplex ES or CE; and then incubated for $24 \mathrm{~h}$ with resazurin. Data are expressed as mean \pm standard deviation (SD) of data from four independent experiments. Statistically significant differences with respect to the control, LPS ${ }_{E}$ coli $026 \mathrm{~B} 6$ or $\mathrm{CpG}$ (ODN1826), ${ }^{*} \mathrm{p}<0.05,{ }^{\alpha} \mathrm{p}<0.01,{ }^{\beta} \mathrm{p}<0.001$ or ${ }^{\gamma} \mathrm{p}<0.0001$, are indicated. C57BL/6J cells incubated with medium alone showed significant increase of SI at $17 \mathrm{~h}(\mathrm{p}<0.05) 21 \mathrm{~h}(\mathrm{p}<0.05), 23 \mathrm{~h}$ and $24(\mathrm{p}<0.01)$. C57BL/6J cells incubated with LPS $E_{E \text {.coli 026B } 6}$ alone showed significant increase of SI at $17 \mathrm{~h}(\mathrm{p}<0.0001), 21 \mathrm{~h}, 23 \mathrm{~h}$ and $24 \mathrm{~h}(\mathrm{p}<0.0001)$. C57BL/6J cells incubated with CpG (ODN1826) alone showed significant increase of SI at $9 \mathrm{~h}(\mathrm{p}<0.01), 17 \mathrm{~h}, 21 \mathrm{~h}, 23 \mathrm{~h}$ and $24 \mathrm{~h}(\mathrm{p}<0.001)$. BALB/c cells incubated with medium alone showed significant increase of SI at $17(\mathrm{p}<0.01) 21 \mathrm{~h}, 23 \mathrm{~h}$ and $24 \mathrm{~h}(\mathrm{p}<0.001)$. BALB/c cells incubated with LPS ${ }_{E \text {.coli } 026 \mathrm{~B} 6}$ alone showed significant increase of SI at $9 \mathrm{~h}(\mathrm{p}<0.05), 17 \mathrm{~h}, 21 \mathrm{~h}, 23 \mathrm{~h}$ and $24 \mathrm{~h}(\mathrm{p}<0.0001)$. BALB/c cells incubated with CpG (ODN1826) alone showed significant increase of SI at $21 \mathrm{~h}(\mathrm{p}<0.05), 23 \mathrm{~h}, 24 \mathrm{~h}(\mathrm{p}<0.05)$.

added for $24 \mathrm{~h}$. Control C57BL/6J and BALB/c cells incubated with medium, LPS or CpG showed significant increase in SI (Fig. 5). In C57BL/6J, excretory-secretory (ES) or crude extract (CE) increased SIs when compared to the negative control of medium. These differences were significant in the case of CE stimulation (Fig. 5A). If C57BL/6J splenocytes were co-stimulated with $\mathrm{ES} / \mathrm{CE}$ and LPS, we observed that ES addition significantly increased SI achieved by LPS alone (Fig. 5B). Similarly, coincubation of $\mathrm{CpG}$ with $\mathrm{ES} / \mathrm{CE}$ significantly augmented SIs achieved by $\mathrm{CpG}$ alone (Fig. 5C). In BALB/c, ES/CE increased SIs in a significant manner compared to control cells or medium (Fig. 5D). Co-incubation with CE significantly increased SIs produced by LPS alone (Fig. 5E). As before, addition of $\mathrm{CpG}$ to $\mathrm{CE}$ produced a significant increase of SIs compared to $\mathrm{CpG}$ alone (Fig. 5F).

SIs were calculated following $24 \mathrm{~h}$ incubation with antigens and controls with the same conditions described above. Control C57BL/6J and BALB/c cells incubated with medium, LPS or CpG showed significant increase of SIs (Fig. 6). In C57BL/6J, addition of CE significantly increased SIs compared to medium (Fig. 6A). Co-stimulation of C57BL/6J splenocytes with ES/CE and LPS significantly increased SIs compared to incubation with
LPS alone (Fig. 6B). Interestingly, the addition of $\mathrm{CpG}$ to $\mathrm{CE}$ significantly inhibited SIs induced by $\mathrm{CpG}$ alone (Fig. 6C). In BALB/c, both larval antigens increased SIs in a significant manner compared to medium (Fig. 6D). No effects were observed when ES/CE were combined either with LPS or with $\mathrm{CpG}$ (Fig. 6E-F).

SIs of splenocytes were calculated following $48 \mathrm{~h}$ incubation with antigens or medium alone and in combination with LPS and CpG. Control C57BL/6J and BALB/c cells incubated with medium, LPS or CpG showed significant increase of SIs (Fig. 7). In the case of C57BL/6J, ES/CE significantly increased SIs compared to the negative control of medium (Fig. 7A). No effects were observed when ES/CE were combined with LPS (Fig. 7B). On the contrary, both antigens produced a significant decrease in the SI when they associated with $\mathrm{CpG}$ (Fig. 7C). None of the two antigens studied produced any change in the SIs produced by their respective controls in BALB/c (Fig. 7D-F).

\section{DISCUSSION}

The evaluation of DC activation can be determined by measuring expression of surface molecules and production of cytokines, but it can also be established by 
A

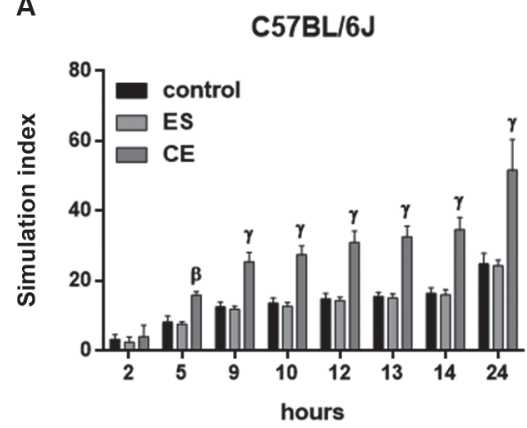

D

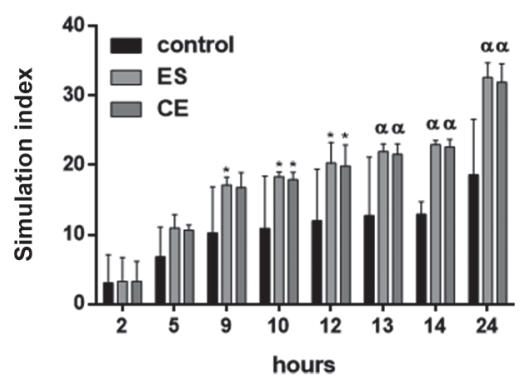

B

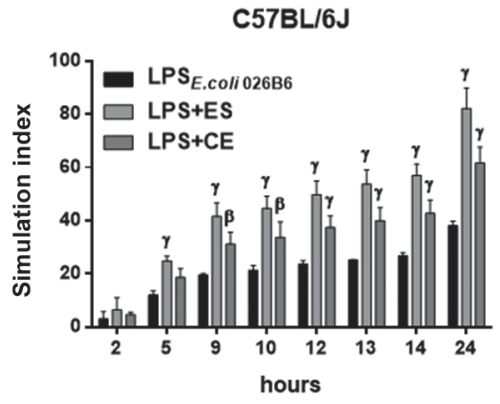

E

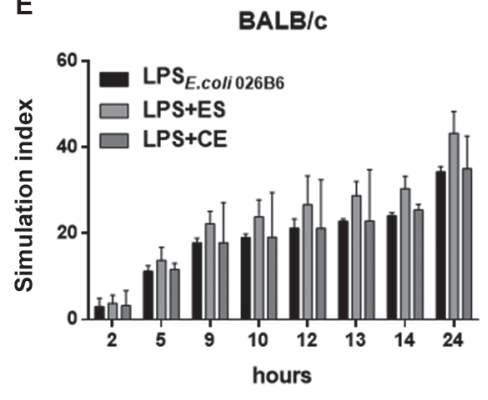

C

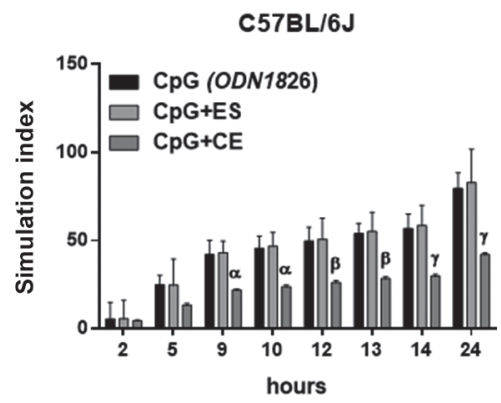

F

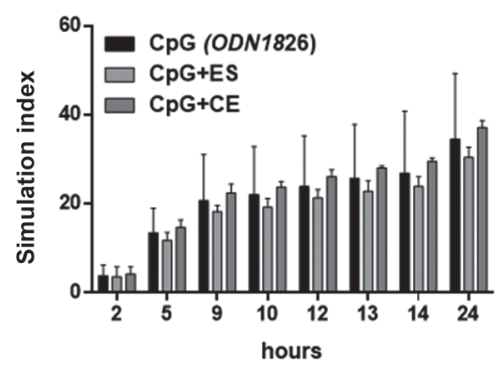

Fig. 6: stimulation index (SI) of C57BL/6J or BALB/c mouse splenocytes after 24 h of stimulation with Anisakis simplex excretory-secretory

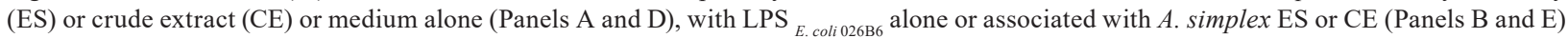
or with CpG (ODN1826) alone or associated with A. simplex ES or CE; and then incubated for $24 \mathrm{~h}$ with resazurin. Data are expressed as mean \pm standard deviation (SD) of data from four independent experiments. Statistically significant differences with respect to the control, LPS ${ }_{E}$. coli $026 \mathrm{~B} 6$ or $\mathrm{CpG}(\mathrm{ODN} 1826),{ }^{*} \mathrm{p}<0.05,{ }^{\alpha} \mathrm{p}<0.01,{ }^{\beta} \mathrm{p}<0.001$ or ${ }^{\gamma} \mathrm{p}<0.0001$, are indicated. C57BL/6J cells incubated with medium alone showed significant increase of SI at $9 \mathrm{~h}(\mathrm{p}<0.001), 10 \mathrm{~h}, 12 \mathrm{~h}, 13 \mathrm{~h}, 14 \mathrm{~h}$ and $24 \mathrm{~h}(\mathrm{p}<0.0001)$. C57BL/6J cells incubated with LPS coli $026 \mathrm{~B} 6$ alone showed significant increase of SI at $9 \mathrm{~h}(\mathrm{p}<0.0001), 10 \mathrm{~h}, 12 \mathrm{~h}, 13 \mathrm{~h}, 14 \mathrm{~h}$ and $24 \mathrm{~h}(\mathrm{p}<0.0001)$. C57BL/6J cells incubated with CpG (ODN1826) alone showed significant increase of SI at $5 \mathrm{~h}(\mathrm{p}<0.05), 9 \mathrm{~h}, 10 \mathrm{~h}, 12 \mathrm{~h}, 13 \mathrm{~h}, 14 \mathrm{~h}$ and $24 \mathrm{~h}(\mathrm{p}<0.0001)$. BALB/c cells incubated with medium alone showed significant increase of SI at $12 \mathrm{~h}(\mathrm{p}<0.05), 13 \mathrm{~h}, 14 \mathrm{~h}(\mathrm{p}<0.05), 24 \mathrm{~h}(\mathrm{p}<0.0001)$. BALB/c cells incubated with LPS coli $_{0268}$ alone showed significant increase of SI $9 \mathrm{~h}(\mathrm{p}<0.01), 10 \mathrm{~h}(\mathrm{p}<0.01), 12 \mathrm{~h}(\mathrm{p}<0.001), 13 \mathrm{~h}, 14 \mathrm{~h}$ and $24 \mathrm{~h}(\mathrm{p}<0.0001)$. BALB/c cells incubated with CpG (ODN1826) alone showed significant increase of SI at $9 \mathrm{~h}(\mathrm{p}<0.01), 10 \mathrm{~h}(\mathrm{p}<0.01), 12 \mathrm{~h}, 13 \mathrm{~h}(\mathrm{p}<0.001), 14 \mathrm{~h}$ and $24 \mathrm{~h}(\mathrm{p}<0.0001)$.

their capability to present antigens to $\mathrm{T}$ cells that leads to their activation and differentiation. In our previous work, we demonstrated that even though murine DCs stimulated in vitro with $A$. simplex larval antigens did not reach a complete activated phenotype, they showed ability to present antigens to $T$ cells and cause polarization. ${ }^{(1)}$ Likewise, Napoletano et al. observed that Anisakis pegreffii generated human DCs with an impaired phenotype as demonstrated by low expression of HLAII- DR and CD86 costimulatory molecules. ${ }^{(9)}$

In this work, co-cultivation of mouse splenocytes with DCs previously stimulated with $A$. simplex larval antigens caused the expansion of $\mathrm{T}_{\text {reas }}$. The frequencies of $\mathrm{CD} 4^{+} \mathrm{CD} 25^{-\mathrm{Foxp}^{+}}{ }^{+}$and $\mathrm{CD} 8^{+} \mathrm{CD} 25^{-\mathrm{F}}{ }^{-}$oxp $3^{+} \mathrm{T}$ cell populations were increased in $\mathrm{C} 57 \mathrm{BL} / 6 \mathrm{~J}$ mice by DCs stimulated with $\mathrm{CE}$, but percentages decreased after incubation with ES. In addition, DCs stimulation with CE decreased the frequency of $\mathrm{CD}^{+} \mathrm{CD} 25^{+} \mathrm{T}$ cells. Conversely, CE stimulation significantly enhanced the expression of $\mathrm{CD} 8^{+} \mathrm{CD} 25^{-}$ $\mathrm{T}$ cells compared to the negative control. Therefore, as with BALB/c mice, tolerogenic DCs promoted by $A$. simplex larval antigens appeared to cause $\mathrm{T}_{\text {reg }}$ expansion.

The study main limitations are a small sample plus high variable standard deviations. Thus, it is difficult to come up with consistent conclusions from the results.
However, it is also important to remember this is an in vitro study, and the goal was to obtain preliminary data that could open the way to the design of future in vivo experiments. Our results may lack homogeneity, but it confirms the dual activity that $A$. simplex has over the immune system of the host, and it is the first study that shows $A$. simplex larval antigens are able to regulate the close interaction between DCs and lymphocytes.

IFN- $\gamma$ expression was raised mainly in $\mathrm{CD} 4^{+} \mathrm{CD} 25^{-}$ and $\mathrm{CD}^{+} \mathrm{CD} 25^{-} \mathrm{T}$ cells after incubation with $\mathrm{CE}$ in $\mathrm{C} 57 \mathrm{BL} / 6 \mathrm{~J}$ mice, and in $\mathrm{CD}^{+} \mathrm{CD} 25^{+} \mathrm{T}$ cells stimulated with $\mathrm{CE}$ and $\mathrm{CD} 4^{+} \mathrm{CD} 25^{-} \mathrm{T}$ cells stimulated with ES in $\mathrm{BALB} / \mathrm{c}$ mice. Likewise, oral administration of Anisakis typica $\mathrm{CE}$ increased significantly $\mathrm{CD} 4+\mathrm{IFN}-\gamma+$ cells in BALB/c mice. ${ }^{(10)}$ This differs with the findings of the study of Heligmosomoides polygyrus, where $\mathrm{CD} 4{ }^{+} \mathrm{CD} 25^{+} \mathrm{T}$ cells did not express IFN- $\gamma \cdot{ }^{(11)}$ However, in vivo experiments carried out in mice using the $A s-$ caris suum antigen PAS-1 demonstrated that $\mathrm{CD}^{+} \gamma \delta^{+} \mathrm{T}$ cells were able to modulate airway allergic inflammation through the production of IFN- $\gamma_{.}^{(12)}$ These results resemble the duality of the immune responses caused by $A$. simplex larval antigens described by us in this work. Ascaris and Anisakis are nematodes that belong to the same Order (Ascaridida); their ability to originate 
A

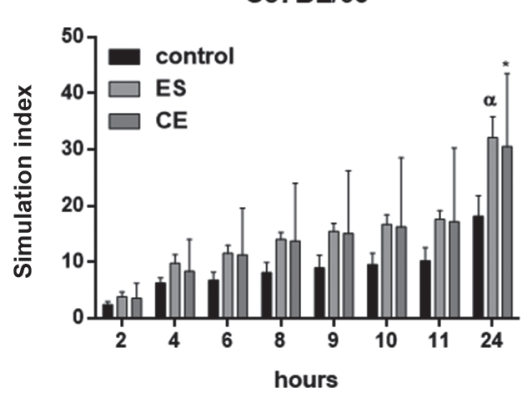

D

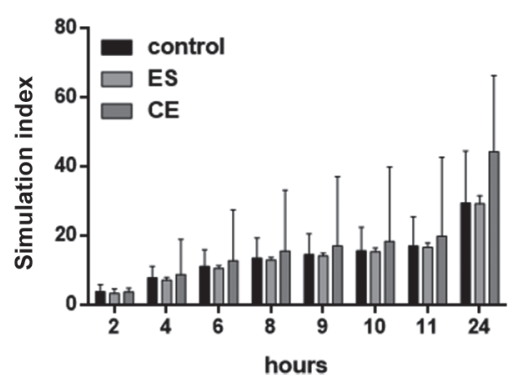

B

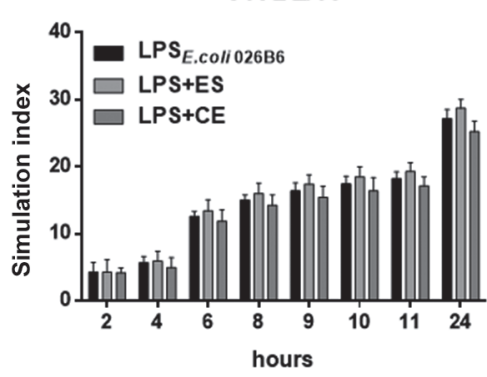

E

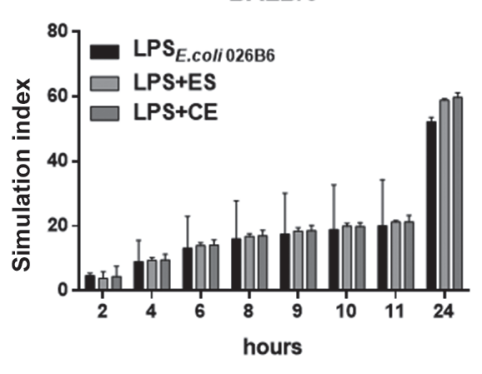

C

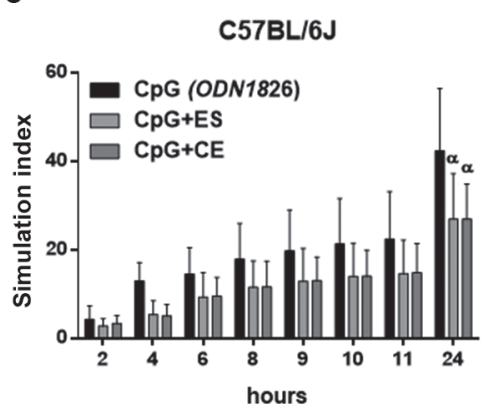

$\mathbf{F}$

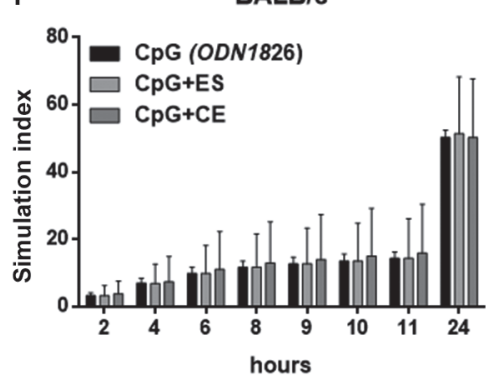

Fig. 7: stimulation index (SI) of C57BL/6J or BALB/c mouse splenocytes after $48 \mathrm{~h}$ of stimulation with Anisakis simplex excretory-secretory (ES) or crude extract (CE) or medium alone (Panels A and D), with LPS ${ }_{E \text { coli } 026 \mathrm{~B} 6}$ alone or associated with A. simplex ES or CE (Panels B and E) or with $\mathrm{CpG}(\mathrm{ODN} 1826)$ alone or associated with $A$. simplex ES or CE; and then incubated for $24 \mathrm{~h}$ with resazurin. Data are expressed as mean \pm standard deviation (SD) of data from four independent experiments. Statistically significant differences with respect to the control, LPS or $\mathrm{CpG}(\mathrm{ODN} 1826),{ }^{*} \mathrm{p}<0.05,{ }^{\alpha} \mathrm{p}<0.01,{ }^{\beta} \mathrm{p}<0.001$ or ${ }^{\gamma} \mathrm{p}<0.0001$, are indicated. C57BL/6J cells incubated with medium alone showed significant increase of SI at $24 \mathrm{~h}(\mathrm{p}<0.05)$. C57BL/6J cells incubated with LPS ${ }_{E \cdot \text { coli } 026 \mathrm{~B} 6}$ alone showed significant increase of SI at $6 \mathrm{~h}(\mathrm{p}<0.0001), 8 \mathrm{~h}$, $9 \mathrm{~h}, 10 \mathrm{~h}, 11 \mathrm{~h}$ and $24 \mathrm{~h}(\mathrm{p}<0.0001)$. C57BL/6J cells incubated with $\mathrm{CpG}(\mathrm{ODN} 1826)$ alone showed significant increase of SI at $10 \mathrm{~h}(\mathrm{p}<0.05)$, $11 \mathrm{~h}(\mathrm{p}<0.05)$ and $24 \mathrm{~h}(\mathrm{p}<0.0001)$. BALB/c cells incubated with medium alone showed significant increase of SI at $24 \mathrm{~h}(\mathrm{p}<0.05)$. BALB/c cells incubated with LPS E. coli $026 \mathrm{~B} 6_{6}$ alone showed significant increase of SI at $10 \mathrm{~h}(\mathrm{p}<0.05), 11 \mathrm{~h}(\mathrm{p}<0.05)$ and $24 \mathrm{~h}(\mathrm{p}<0.0001)$. BALB/c cells incubated with $\mathrm{CpG}$ (ODN1826) alone showed significant increase of SI at $24 \mathrm{~h}(\mathrm{p}<0.0001)$.

allergic responses in their hosts, ${ }^{(13)}$ where $\mathrm{T}_{\text {reg }}$ populations develop and IFN- $\gamma$ is produced, has been well established. Studies demonstrating that IFN- $\gamma$ possesses immune regulatory ability and is implicated in allergic responses are becoming more abundant. ${ }^{(14)}$ Recently, Jung et al. ${ }^{(15)}$ demonstrated the key role of IFN- $\gamma$ in the induction of colitis in mice after intratracheal ovalbumin exposure. In addition, Chen and $\mathrm{Liu}^{(16)}$ demonstrated the immunoregulatory ability of $\mathrm{CD} 4^{+} \mathrm{IL}-10^{+} \mathrm{IFN}-\gamma^{+} \mathrm{T}$ cells, as well as their implication in chronic infections. IL-10 expression would prevent an excessive acute response from the host, inhibiting the production of IL-12 and, concomitantly, the development of a Th2 response. Besides, IFN- $\gamma$ could increase a Th1 response and production of IL-27 by antigen presenting cells (APCs). Finally, APCs could activate CD4+IL-10 ${ }^{+} \mathrm{IFN}-\gamma^{+} \mathrm{T}$ cells. Despite this evidence, there is great controversy about the phenotype and function of regulatory populations, so it is difficult to draw strong conclusions based on the literature. For example, H. polygyrus treated DCs were able to generate in vitro $\mathrm{CD} 4^{+} \mathrm{CD} 25^{+} \mathrm{T}$ cells that secrete IL-10 but did not express Foxp3. ${ }^{(11)}$ On the other hand, Wang et al. ${ }^{(17)}$ showed that Echinococcus granulosus ES-treated DC co-cultures expanded the frequency of
$\mathrm{CD} 4{ }^{+} \mathrm{CD} 25^{+} \mathrm{Foxp}^{+} \mathrm{T}$ cells whose regulatory role, interpreted as a potential mechanism of immune evasion, was independent of IL-10. Tang et al. ${ }^{(18)}$ also demonstrated that $\mathrm{CD} 4^{+} \mathrm{CD} 25^{+} \mathrm{T}_{\text {regs }}$ play an important role on the Schistosoma japonicum immune evasion from the host immune response. In our experimental conditions, BALB/c mice showed a significant decrease of $\mathrm{CD} 4^{+}$and $\mathrm{CD} 8^{+} \mathrm{T}$ cells after co-culture with DCs exposed to A. simplex antigens. This finding was associated with higher levels of $\mathrm{CD}^{+} \mathrm{CD}^{2} 5^{+} \mathrm{Foxp}^{+}{ }^{+}$and $\mathrm{CD} 8^{+} \mathrm{CD} 25^{+} \mathrm{Foxp}^{+} \mathrm{T}_{\text {regs }}$ as well as with higher percentages of IL- $10^{+}$cells within both $\mathrm{CD} 4^{+} \mathrm{CD} 25^{+}$and $\mathrm{CD} 8^{+} \mathrm{CD} 25^{+} \mathrm{T}$ cell subsets, supporting a regulatory phenotype. These outcomes are consistent with the ability of $\mathrm{CD} 4^{+} \mathrm{CD} 25^{+} \mathrm{T}_{\text {regs }}$ of suppressing $\mathrm{CD} 4^{+}$ and $\mathrm{CD} 8^{+} \mathrm{T}$ cells by a direct contact mechanism and by IL-10 secreted by $\mathrm{CD} 4+\mathrm{CD} 25^{+} \mathrm{T}_{\text {regs }}{ }^{(19)}$

The development of immature and incompletely activated DCs has been described for $H$. polygyrus in similar experimental conditions. In those studies, DCs induced the proliferation of $\mathrm{CD} 4{ }^{+} \mathrm{CD} 25^{+} \mathrm{T}$ cells that produced IL10 in vitro, and inhibited proliferation of IFN- $\gamma$ producing cells. These data suggested that the ES antigens of H. polygyrus were able to inhibit both Th1 and Th2 responses by an increase on a $\mathrm{CD} 4{ }^{+} \mathrm{CD} 25^{+} \mathrm{T}$ cell suppres- 
sor population. ${ }^{(11)}$ In fact, it has been described that $\mathrm{T}_{\text {regs }}$ are involved in both allergic and autoimmune responses (Th2 and Th1, respectively). ${ }^{(20)}$ It is noteworthy that $A$. simplex and $H$. polygyrus are intestinal parasites, and that $\mathrm{T}_{\text {regs }}$ differentiation induced by intestinal DCs exposed to helminths is one of the main mechanisms that lead to immunomodulation..$^{(1)}$ Junginger et al. ${ }^{(21)}$ also demonstrated elevated rates of Foxp $3^{+}$lymphocytes in the intestinal mucosa of nematode-infected dogs. Taken together, the reported results in BALB/c mice, suggest a new mechanism by which $A$. simplex larval antigens are able to immunomodulate the immune system unknown until now; i.e., generation of $\mathrm{T}_{\text {regs }}$ by immature DCs.

Together, these results suggest that $A$. simplex larval antigens can stimulate tolerogenic DCs that could lead to $\mathrm{T}_{\text {regs }}$ in vitro. Tolerogenic DCs would produce moderate amounts of IL-12 and TNF- $\alpha$, which would promote the expansion of T cells producers of IFN- $\gamma$ (Th1 response).

The development of these apparently opposed responses could be related to the two different mouse strain phenotypes: the more susceptible BALB/c and the more resistant C57BL/6J. As it was previously reported, $A$. simplex antigens promoted both immature and inflammatory DCs with a higher percentage of CD11 $\mathrm{c}^{+} \mathrm{IL}-10^{+}$ cells in C57BL/6J mice at $24 \mathrm{~h}$ of stimulation with larval antigens. ${ }^{(1)}$ Furthermore, the expression of cytokines that exert opposing effects, could be consider as an autoregulatory mechanism: IL-10-producing $\mathrm{T}$ cell populations could inhibit initial Th1 and Th2 responses, while IFN$\gamma$-producing $\mathrm{T}$ cell populations could promote a Th1 response but at the same time stimulate the production of IL-10 in order to avoid an excess of inflammation. Providing that the production of IL-10 and IFN- $\gamma$ is in harmony, Th1 and Th2 responses would stay apart, and a regulatory phenotype would prevail.

Murine immune responses to $A$. simplex infection are complex and entail Th2 predominance over Th1 at the beginning. ${ }^{(8)}$ Similar results have been described in humans. ${ }^{(22)}$ According to our study, A. simplex infection could be accompanied by tolerogenic DCs activation, leading to $\mathrm{T}_{\text {reg }}$ populations which could produce IL-10 and IFN- $\gamma$. Although there are not many studies regarding the effect of $A$. simplex larval antigens on cell proliferation, Raybourne et al. ${ }^{(23)}$ reported that $A$. simplex ES larval antigens were able to inhibit lymphoproliferation in cells activated by Concanavalin A and bacterial LPS.

Resazurin-based proliferation assays are fast and reproducible methods to quantify lymphocyte mitochondrial activity that appear to accurately reflect cell numbers in a linear fashion and can be continuously monitored over time. ${ }^{(24)}$ In our study, we investigated the effect of A. simplex larval antigens alone or with the mitogens LPS/CpG in naïve murine splenocytes compared to a negative control and the mitogens alone. We also compared $\mathrm{BALB} / \mathrm{c}$ and $\mathrm{C} 57 \mathrm{BL} / 6 \mathrm{~J}$ responses. In both strains, ES and especially CE appear to stimulate the mitochondrial respiratory activity respect to the negative control. This could be explained in vivo due to granuloma formation. ES antigens released by living larvae induce a neutrophilic infiltration in an early stage, which is then replaced by eosinophils as the granuloma matures and larvae are killed. In contrast, $\mathrm{CE}$ antigens released by parasite damage exhibit a potent chemotactic activity for eosinophils, inducing intense eosinophilic phlegmonous reactions. ${ }^{(25)}$ Therefore, ES could potentially skew the immune response towards a Th2 response, while CE could be causing Th1 polarization.

On the other hand, the association of ES or CE with LPS produced different responses after $24 \mathrm{~h}$ of stimulation: in BALB/c mice, neither ES nor CE modified the mitochondrial respiratory activity caused by LPS alone (already higher than the negative control of medium), while in C57BL/6J mice, ES and CE increased the effect of LPS activation. The fact that the addition of A. simplex antigens did not show any effects on the response of LPS in BALB/c mice but did in C57BL/6J mice clearly demonstrates the divergent responses of both strains. Previous studies have shown that the monocyte/macrophage LPS response is slightly regulated by IL-10 and IL-12. (26) $\mathrm{BALB} / \mathrm{c}$ mice are highly reactive to $A$. simplex antigens, generating an acute inflammatory response, with higher expression of IL-12 and lower expression of IL-10 than $\mathrm{C} 57 \mathrm{BL} / 6 \mathrm{~J}$ mice. ${ }^{(1)}$ Interestingly, TLR4 expression is higher in $\mathrm{BALB} / \mathrm{c}$ compared to $\mathrm{C} 57 \mathrm{BL} / 6 .{ }^{(27)}$

Conversely, co-incubation of $\mathrm{CE}$ with $\mathrm{CpG}$ clearly decreased the mitochondrial respiratory activity caused by $\mathrm{CpG}$ alone in $\mathrm{C} 57 \mathrm{BL} / 6 \mathrm{~J}$ mice, a strain that expresses higher levels of TLR9 compared to BALB/c. ${ }^{(27)}$ This inhibitory effect was also observed after $48 \mathrm{~h}$ of stimulation with ES/CE, while no change was observed in BALB/c. IL-10 has several functions, including inhibit cellular proliferation. ${ }^{(28)}$ Thus, it is not surprising that C57BL/6J mice, which released higher levels of IL-10 (compared to BALB/c), showed a decrease in the mitochondrial respiratory activity caused by $\mathrm{CpG}$ alone. Likewise, BALB/c and C57BL/6, display dramatically different mucosal immune responses. ${ }^{(29)}$ Therefore, the immune response developed to A. simplex will not only depend on the own regulatory mechanism of the parasite, but also of the host genetic phenotype ${ }^{(30)} \mathrm{BALB} / \mathrm{c}$ mice would match with the helminth infection resistant phenotype, characterized by acute inflammatory reactions and a Th2 response common in endemic helminth areas, while C57BL/6J mice would represent the nonresistant phenotype, with the infection development and more moderate/chronic infection. ${ }^{(22)}$

Similar results have been described in other parasites like $H$. polygyrus. This parasite presents a Th2 response accompanied with an activation of $\mathrm{T}_{\text {regs }}$ and Th1 cytokine inhibition. ${ }^{(7)}$ Necator americanus is also well-known for inhibit cellular proliferation. ${ }^{(31)}$ However, the mechanisms involved in supressing $\mathrm{T}$ lymphocyte proliferation are not clear yet, but include IL-10 production, release of IFN- $\gamma$ by NK cells, ${ }^{(32)}$ direct action of parasite antigens ${ }^{(31)}$ and reduced expression of TLRs. ${ }^{(33)}$ The results of this study agree to other studies in other helminths like H. polygyrus or $N$. americanus, which also seem to inhibit T cell proliferation. Even though $A$. simplex larval antigens not always caused an inhibition of proliferation and this inhibition is strain dependent, our results suggest that $A$. simplex may exert regulatory. Our work also confirms that hosts genetics are essential for the development of $\mathrm{Th} 2$ or $\mathrm{T}_{\text {regs }}$ cells. 
In conclusion, incubation with ES and CE larval antigens of A. simplex induce tolerogenic DCs that increase the frequency of regulatory $\mathrm{T}$ lymphocytes in vitro, which in turn produce IL-10 and IFN- $\gamma$. These cytokines could supress the development of Th1 and/ or Th2 responses at the beginning of the infection. Moreover, the effects observed of the A. simplex larval antigens on the lymphoproliferation assays suggest unknown regulatory mechanisms of this parasite and confirm that the host genetic base is essential in the development of one immune response predominant over the others (Th2, Th1, $\mathrm{T}_{\mathrm{reg}}$ ). Thus, differences in the reactivities of lymphocytes to ES/CE antigens through TLRs may underlie resistance and susceptibility of human patients to A. simplex infection.

\section{AUTHORS' CONTRIBUTION}

$\mathrm{CC}$ and SM - Conception and design of the work; VZ, MR and and AI-E - collecting data; VZ and MR - flow cytometry analysis; VZ and AI-E - proliferation assay; JCA-B - statistical method; CC, VZ, MR, AI-E, JCA-B and SM - interpretation of data for the work; $\mathrm{CC}, \mathrm{VZ}$ and $\mathrm{SM}$ - drafting the work and revising it critically for important intellectual content.

\section{REFERENCES}

1. Zamora V, Rodero M, Andreu-Ballester JC, Mendez S, Cuéllar C. Induction of tolerogenic properties by Anisakis larval antigens on murine dendritic cells. Parasite Immunol. 2019; 41(4): e12616.

2. Muthana M, Fairburn B, Mirza S, Slack LK, Hopkinson K, Pockley AG. Identification of a rat bone marrow-derived dendritic cell population which secretes both IL-10 and IL-12: evidence against a reciprocal relationship between IL-10 and IL-12 secretion. Immunobiology. 2006; 211(5): 391-402.

3. Xu J, Zhang H, Chen L, Zhang D, Ji M, Wu H, et al. Schistosoma japonicum infection induces macrophage polarization. J Biomed Res. 2014; 28(4): 299-308.

4. Sofronic-Milosavljevic L, Ilic N, Pinelli E, Gruden-Movsesijan A. Secretory products of Trichinella spiralis muscle larvae and immunomodulation: implication for autoimmune diseases, allergies, and malignancies. J Immunol Res. 2015; 2015: 523875.

5. Harris NL, Loke P. Recent advances in Type-2-Cell-Mediated immunity: insights from helminth infection. Immunity. 2018; 47(6): 1024-36.

6. Allen JE, Wynn TA. Evolution of Th2 immunity: a rapid repair response to tissue destructive pathogens. PLoS Pathog. 2011; 7(5): e1002003.

7. Maizels RM, McSorley HJ. Regulation of the host immune system by helminth parasites. J Allergy Clin Immunol. 2016; 138(3): 666-75.

8. Perteguer MJ, Cuéllar C. Isotype-specific immune responses in murine experimental anisakiasis. Zentralbl Veterinarmed B. 1998; 45(10): 603-10.

9. Napoletano C, Mattiucci S, Colantoni A, Battisti F, Zizzari IG, Rahimi $\mathrm{H}$, et al. Anisakis pegreffii impacts differentiation and function of human dendritic cells. Parasite Immunol. 2018; 40(5): e12527.

10. Haryadi L, Suprayitno E, Aulanni'am A, Hariati AM. Immune response evaluation in Balb/c mice after crude extract of Anisakis typica sensitization. Vet World. 2019; 12(10): 1529-34.

11. Segura M, Su Z, Piccirillo C, Stevenson MM. Impairment of dendritic cell function by excretory-secretory products: a potential mechanism for nematode-induced immunosuppression. Eur J Immunol. 2007; 37(7): 1887-904.
12. Araújo CA, Perini A, Martins MA, Macedo MS, Macedo-Soares MF. PAS-1, an Ascaris suum protein, modulates allergic airway inflammation via $\mathrm{CD} 8+\gamma \delta \mathrm{TCR}+$ and $\mathrm{CD} 4+\mathrm{CD} 25+\mathrm{FoxP} 3+\mathrm{T}$ cells. Scand J Immunol. 2010; 72(6): 491-503.

13. Cooper PJ. Interactions between helminth parasites and allergy. Curr Opin Allergy Clin Immunol. 2009; 9(1): 29-37.

14. Gaudieri S, Tulic MK, Lucas A, Lucas M. IFN- $\lambda$ and IgE-mediated allergic disease: a potential future role? Biomark Med. 2012; 6(2): 151-7.

15. Jung KH, Shin D, Kim S, Min D, Kim W, Kim J, et al. Intratracheal ovalbumin administration induces colitis through the IFN- $\gamma$ pathway in mice. Front Immunol. 2019; 10: 530.

16. Chen J, Liu XS. Development and function of IL-10 IFN-gammasecreting CD4(+) T cells. J Leukoc Biol. 2009; 86(6): 1305-10.

17. Wang Y, Zhou H, Shen Y, Wang Y, Wu W, Liu H, et al. Impairment of dendritic cell function and induction of CD4(+)CD25(+) Foxp3(+) T cells by excretory-secretory products: a potential mechanism of immune evasion adopted by Echinococcus granulosus. BMC Immunol. 2015; 16: 44.

18. Tang CL, Lei JH, Wang T, Lu SJ, Guan F, Liu WQ, et al. Effect of $\mathrm{CD} 4+\mathrm{CD} 25+$ regulatory $\mathrm{T}$ cells on the immune evasion of Schistosoma japonicum. Parasitol Res. 2011; 108(2): 477-80.

19. Laidlaw BJ, Craft JE, Kaech SM. The multifaceted role of CD4(+) T cells in CD8(+) T cell memory. Nat Rev Immunol. 2016; 16(2): 102-11.

20. Else KJ. Have gastrointestinal nematodes outwitted the immune system? Parasite Immunol. 2005; 27(10-11): 407-15.

21. Junginger J, Schwittlick U, Lemensieck F, Nolte I, HewickerTrautwein M. Immunohistochemical investigation of Foxp3 expression in the intestine in healthy and diseased dogs. Vet Res. 2012; 43(1): 23.

22. Daschner A, Cuéllar C. The hidden sense of symptoms: urticaria can be beneficial. Med Hypotheses. 2010; 75(6): 623-6.

23. Raybourne R, Desowitz RS, Kliks MM, Deardorff TL. Anisakis simplex and Terranova sp.: inhibition by larval excretory-secretory products of mitogen-induced rodent lymphoblast proliferation. Exp Parasitol. 1983; 55(3): 289-98.

24. Koyanagi M, Kawakabe S, Arimura Y. A comparative study of colorimetric cell proliferation assays in immune cells. Cytotechnology. 2016; 68(4): 1489-98.

25. Jones RE, Deardorff TL, Kayes SG. Anisakis simplex: histopathological changes in experimentally infected CBA/J mice. Exp Parasitol. 1990; 70(3): 305-13.

26. Pils MC, Pisano F, Fasnacht N, Heinrich JM, Groebe L, Schippers A, et al. Monocytes/macrophages and/or neutrophils are the target of IL-10 in the LPS endotoxemia model. Eur J Immunol. 2010; 40(2): 443-8.

27. Liu T, Matsuguchi T, Tsuboi N, Yajima T, Yoshikai Y. Differences in expression of toll-like receptors and their reactivities in dendritic cells in BALB/c and C57BL/6 mice. Infect Immun. 2002; 70(12): 6638-45.

28. Taga K, Tosato G. IL-10 inhibits human T cell proliferation and IL-2 production. J Immunol. 1992; 148(4): 1143-8.

29. Busch RA, Jonker MA, Pierre JF, Heneghan AF, Kudsk KA. Innate mucosal immune system response of $\mathrm{BALB} / \mathrm{c}$ vs $\mathrm{C} 57 \mathrm{BL} / 6$ mice to injury in the setting of enteral and parenteral feeding. JPEN J Parenter Enteral Nutr. 2016; 40(2): 256-63.

30. Sánchez-Velasco P, Mendizábal L, Antón EM, Ocejo-Vinyals G, Jerez J, Leyva-Cobián F. Association of hypersensitivity to the nematode Anisakis simplex with HLA class II DRB1*1502DQB1*0601 haplotype. Hum Immunol. 2000; 61(3): 314-9. 
$10 \mid 10$ Vega Zamora et al.

31. Geiger SM, Massara CL, Bethony J, Soboslay PT, Corrêa-Oliveira R. Cellular responses and cytokine production in post-treatment hookworm patients from an endemic area in Brazil. Clin Exp Immunol. 2004; 136(2): 334-40.

32. Hsieh GC, Loukas A, Wahl AM, Bhatia M, Wang Y, Williamson $\mathrm{AL}$, et al. A secreted protein from the human hookworm Necator americanus binds selectively to NK cells and induces IFN-gamma production. J Immunol. 2004; 173(4): 2699-704.

33. Hartgers FC, Obeng BB, Kruize YC, Duijvestein M, de Breij A, Amoah A, et al. Lower expression of TLR2 and SOCS-3 is associated with Schistosoma haematobium infection and with lower risk for allergic reactivity in children living in a rural area in Ghana. PLoS Negl Trop Dis. 2008; 2(4): e227. 